\title{
Enhanced luminescence enzyme immunoassay for factor VIII related antigen
}

\author{
HX WANG, J GEORGE, ${ }^{*}$ GHG THORPE, RA STOTT, LJ KRICKA, TP WHITEHEAD \\ From the Department of Clinical Chemistry, Wolfson Research Laboratories, and ${ }^{*}$ Department of \\ Haematology, Queen Elizabeth Medical Centre, Birmingham
}

SUMMARY A sandwich enzyme immunoassay for plasma factor VIII related antigen has been developed which exploits a para-iodophenol enhanced chemiluminescent reaction to detect the horseradish peroxidase label. The assay entailed $15 \mathrm{~min}$ incubations with sample and with conjugate and had a detection limit of $0.12 \mathrm{mU}$. It showed good within batch precision (coefficient of variation $=2 \cdot 95-5 \cdot 8 \%$ ) and results on a series of 57 specimens agreed with results obtained by immunoelectrophoresis (correlation coefficient $=0 \cdot 97$ ).

Factor VIII is a complex consisting of two major subunits: VIII:C and VIIIR:Ag, with molecular weights of $2.85 \times 10^{5}$ and $1-2 \times 10^{6}$ respectively. It is a cofactor of factor IXa, which is involved in the conversion of factor $\mathrm{X}$ to $\mathrm{Xa}$ in the blood coagulation process.' Deficiency of factor VIIIR:C is found in haemophilia $A$, while qualitative and quantitative deficiency of factor VIIIR:Ag with corresponding decrease in factor VIII:C is manifest as von Willebrand's disease.

Several methods have been used to measure factor VIIIR: $\mathbf{A g}^{\mathbf{2 - 8}}$ including immunoelectrophoresis ${ }^{2}$ and, more recently, enzyme immunoassay. ${ }^{5-8}$ The latter technique avoids the hazards of radioisotopes and is sensitive. The recently discovered enhanced luminescent assay for horseradish peroxidase labels provides a sensitive and rapid end point for enzyme immunoassays based on peroxidase labels. ${ }^{9}$ In this paper we describe the application of enhanced luminescence in an enzyme immunoassay for factor VIII:Ag. The assay is carried out on a black plastic microtitre plate and light emission from individual wells in the plate is monitored using a luminescence microtitre plate reader.

\section{Material and methods}

Phosphate buffered saline tablets were purchased from Oxoid Ltd (Basingstoke, UK). Dimethyl sulphoxide, Tween 20 , hydrogen peroxide $(30 \% \mathrm{vol} /$ vol), luminol, and Trizma base were from Sigma Chemical Company (Poole, UK), and para- iodophenol was from Aldrich Chemical Company (Gillingham, UK). Luminol was purified and converted to its sodium salt by recrystallisation from hot sodium hydroxide and decolorisation with charcoal. ${ }^{10}$ Black polystyrene microtitre plates (MicroFLUOR B) were obtained from Dynatech Laboratories Inc (Alexandria, Virginia, USA).

\section{ANTISERA AND CONJUGATE}

The IgG fraction of rabbit antihuman factor VIII related antigen and its horseradish peroxidase conjugate were supplied by Dakopatts (Copenhagen, Denmark).

\section{STANDARD PLASMA}

A series of standards was prepared by serially diluting the 11th British Standard for blood coagulation factor VIII" in phosphate buffered saline (PBS) $(0 \cdot 1 \mathrm{~mol} / \mathrm{l}, \mathrm{pH} 7 \cdot 3)$ containing Tween $20(1 \mathrm{ml} / \mathrm{l})$.

\section{PLASMA SAMPLES}

Blood was taken into trisodium citrate $(38 \mathrm{~g} / \mathrm{l} ; 1$ part to 9 parts of blood). After centrifugation $(3000 \mathrm{~g}$, $4^{\circ} \mathrm{C}$ ) the plasma was removed and stored in $0.5 \mathrm{ml}$ aliquots in capped plastic tubes at $-20^{\circ} \mathrm{C}$. Factor VIIIR:Ag was measured by immunoelectrophoresis and the enhanced luminescence enzyme immunoassay in a series of samples from 32 healthy controls, four haemophiliacs, four patients with sickle cell disease, ${ }^{12}$ and 16 patients with von Willebrand's disease.

IMMUNOELECTROPHORESIS

This was performed using agarose (Mercia- 
Brocades) containing antihuman factor VIIIR:Ag (Dakopatts), and the 11th British Standard and standards supplied by Immuno Diagnostica (Vienna, Austria), according to the method of Laurell as modified by Zimmerman et al. ${ }^{2}$

\section{ENZYME IMMUNOASSAY}

One hundred microlitres of a 1/500 dilution of antihuman factor VIIIR: Ag in carbonate buffer $\mathbf{( 0 . 0 5}$ $\mathrm{mol} / \mathrm{l}, \mathrm{pH} 9.6$ ) was added to each well of a black microtitre plate, which was then incubated and gently agitated in a moist chamber at room temperature for $15 \mathrm{~min}$. The contents were aspirated and the plate washed three times by immersion in an agitated solution of PBS containing Tween $20(0.5$ $\mathrm{ml} / \mathrm{l}$ ) for $3 \mathrm{~min}$. The plate was dried by gently tapping it on to absorbent paper. One hundred microlitres of a 1/50 dilution of standard or a plasma sample in PBS containing Tween $20(1 \mathrm{ml} / \mathrm{l})$ was added to the plate, which was then incubated for $15 \mathrm{~min}$ and washed three times as before. One hundred microlitres of a 1/500 dilution of the antihuman factor VIIIR:Ag-peroxidase conjugate in PBS containing Tween $20(1 \mathrm{ml} / \mathrm{l})$ was then added to each of the wells of the microtitre plate; the plate was incubated for $15 \mathrm{~min}$, washed three times, and dried as before.

Bound conjugate was detected by adding to each well 100 microlitres of a luminol-hydrogen peroxide-iodophenol solution prepared by adding $1 \mathrm{ml}$ of para-iodophenol ( $40 \mathrm{mmol} / \mathrm{l}$ in DMSO) to $100 \mathrm{ml}$ of a luminol $(1.25 \mathrm{mmol} / \mathrm{l})$ and hydrogen peroxide $(2.7 \mathrm{mmol} / \mathrm{l})$ mixture in Tris buffer $(0.1 \mathrm{~mol} / \mathrm{l}, \mathrm{pH}$ $8 \cdot 5)$. The glowing plate was placed in the microtitre plate reader and the intensity of light emission from individual wells measured within one minute of

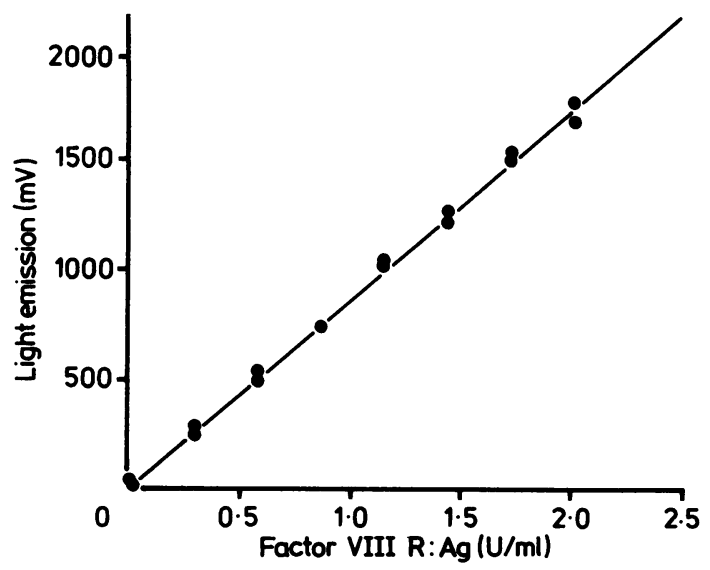

Fig. 1 Standard curve for the enhanced luminescence enzyme immunoassay for plasma factor VIII related antigen.

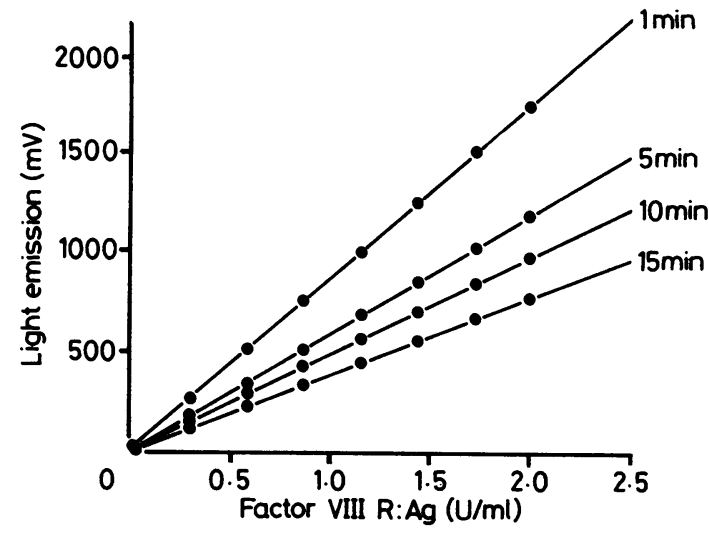

Fig. 2 Inftuence on the standard curve of the time at which measurement of light emission is made after initiation of the enhanced luminescence reaction.

initiation. Light was detected using a photomultiplier tube (9924A, Thorn EMI Electron Tubes Ltd, Ruislip, UK) in a photocurrent mode. The end window photomultiplier tube was fitted with a small circular aperture and positioned close to the upper surface of a microtitre plate contained in a light tight box. The light emission from the luminescence substrate solution was also measured and this blank subtracted from the values obtained for plasma samples. Plasma factor VIIIR:Ag concentrations were obtained by extrapolation from a standard curve of intensity of light emission versus factor VIIIR:Ag concentration.

\section{PRECISION STUDY}

Samples of specimens with high, medium, and low concentrations of factor VIIIR:Ag were analysed repeatedly $(n=12)$ within the same batch.

\section{Results}

The detection limit of the assay based on the amount of factor VIIIR: Ag which produced twice the light emission of the zero standard was $0.12 \mathrm{mU}$. Using sensitised plates, the assay took less than $50 \mathrm{~min}$ to complete and this rose to just over $1 \mathrm{~h}$ if the time taken to sensitise the microtitre plate was included. A typical factor VIIIR:Ag standard curve is shown in Fig. 1. One of the characteristics of the enhanced luminescence assay for the peroxidase label is that the light emission is relatively stable and therefore light emission can be measured several minutes after initiation of the luminescent reaction. The influence of the time at which light emission was measured after initiation on the standard curve is presented in Fig. 2. Acceptable standard curves were obtained 


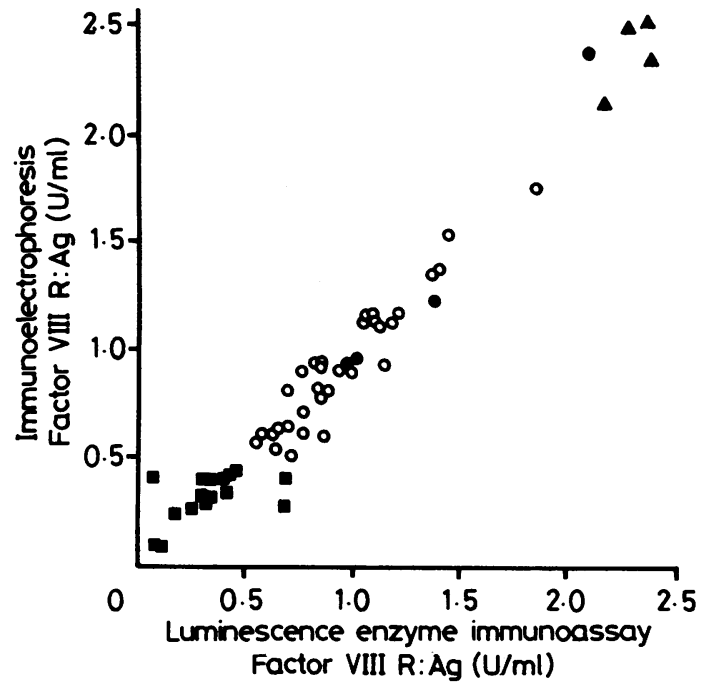

Fig. 3 Correlation of plasma factor VIII related antigen determined by immunoelectrophoresis and enhanced luminescence enzyme immunoassay ( $O$, healthy controls; $\mathrm{a}$, von Willebrand's disease; $\bigcirc$, haemophilia; $\Delta$, sickle cell disease).

from measurements made up to 15 min after initiation of the luminescent reaction.

The assay showed good within batch precision. At factor VIIIR: $\mathrm{Ag}$ concentrations of $0.25,0.85$, and $2.18 \mathrm{U} / \mathrm{ml}$, coefficients of variation of $5 \cdot 8,3.4$, and $3.0 \%$ respectively were obtained $(n=12)$. Good correlation (correlation coefficient $=0.97$ ) was obtained between results from 57 specimens assayed using the enhanced luminescence enzyme immunoassay and immunoelectrophoresis (Fig. 3).

\section{Discussion}

This factor VIIIR:Ag assay is sensitive and can be performed much more quickly than corresponding enzyme immunoassays with colorimetric end points. Others have tried to reduce the incubation times of a colorimetric enzyme immunoassay for factor VIIIR: $\mathrm{Ag}$ - for example, $1 \mathrm{~h}$ to $30 \mathrm{~min}$ incubations with sample and with conjugate-but this reduced assay sensitivity. ${ }^{8}$ The increased speed of the assay is due to several factors. The sensitivity of the enhanced luminescence end point permits shorter incubations of the sensitised microtitre plate with samples and with conjugate, and the luminescence measurement can be made less than $30 \mathrm{~s}$ after initiation compared with $\mathbf{3 0}$ min (typically) for a colorimetric end point. The convenience of the assay was improved by the availability of a prototype manual microtitre plate reader designed for luminescence measurements. This measured the luminescence from individual wells in less than $2 \mathrm{~s}$ and facilitated rapid successive measurements from wells on the plate.

An enhanced luminescence end point is applicable to any enzyme immunoassay which uses a horseradish peroxidase label. It can improve sensitivity and reduce the time taken to complete an assay. Further improvements in -assay speed may be possible by combining enhanced luminescence with monoclonal antibody reagents which allow simultaneous rather than sequential incubation of immobilised antibody with sample and conjugate. ${ }^{13}$

The financial support of the Department of. Health and Social Security and the World Health Organisation is gratefully acknowledged.

\section{References}

I Van Dieijen G, Tans G, Rosing J, Hemket HC. The role of phospholipid and factor VIIIa in the activation of bovine factor X.J Biol Chem 1981;256:3433-42.

${ }^{2}$ Zimmerman TS, Ratnoff OD, Littell AS. Detection of carriers of classic hemophilia using an immunologic assay for antihemophilic factor (factor VIII). J Clin Invest 1971;50:255-8.

${ }^{3}$ Peake IR, Bloom AL. The use of an immunoradiometric assay for factor VIII related antigen in the study of atypical von Willebrand's disease. Thromb Res 1977;10:27-32.

4 Hoyer LW. Immunologic studies of antihemophilic factor (AHF, factor VIII): IV. Radioimmunoassay of AHF antigen. J Lab Clin Med 1972;80:822-33.

s Fishman DJ, Jones PK, Menitove JE, Ratnoff OD, Everson B. Detection of the carrier state for classic hemophilia using an enzyme-linked immunosorbent assay (ELISA). Blood 1982;59:1163-8.

- Bartlett A, Dormandy KM, Hawkey CM, Stapleforth P, Voller A. Factor-VIII-related antigen: measurement by enzyme immunoassay. Br Med J 1976;1:994-6.

7 Yorde LD, Hussey CV, Yorde DE, Sasse EA. Competitive enzyme-linked immunoassay for factor VIII antigen. Clin Chem 1979;25:1924-27.

short PE, Williams CE, Picken AM, Hill FGH. Factor VII related antigen: an improved enzyme immunoassay. Med Lab Sci 1982;39:351-5.

' Kricka LJ, Thorpe GHG, Whitehead TP. Enhanced luminescent or luminometric assay. European Patent Publication 1983;116, 454.

${ }^{10}$ Ham G, Belcher R, Kricka LJ, Carter TJN. Stability of trace iodine solutions. Anal Lett 1979;12:533-41.

"National Institute for Biological Standards and Control, Holly Hill, Hampstead, London, UK.

12 Richardson SGN, Matthews KB, Stuart J, Geddes AM, Wilcox RM. Serial changes in coagulation and viscosity during sickle cell crises. Br J Haematol 1979;41:95-103.

${ }^{13}$ Yolken RH, Leister FJ. Investigation of enzyme immunoassay time course: development of rapid assay systems. J Clin Microbiol 1981;13:738-41.

Requests for reprints to: Dr LJ Kricka, Department of Clinical Chemistry, Queen Elizabeth Medical Centre, Edgbaston, Birmingham B15 2TH, England. 